\title{
Influence of Logistic Performance, Exchange Rate, Interest Rate and Net Export on Global Competitiveness and Their Implications on Economic Growth (Case Study of ASEAN Countries and Several South Asian and East Asian Countries)
}

\author{
Wahyu Widayat ${ }^{1}$, Heru Subiyantoro ${ }^{2}$, Machfud Sidik $^{3}$ \\ \{wahyu_murti@borobudur.ac.id ${ }^{1}$, heru_subiyantoro@borobodur.ac.id ${ }^{2}$, machfud_sidik@gmail.com ${ }^{3}$ \} \\ Universitas Borobudur, Jakarta, Indonesia ${ }^{1,2,3}$
}

\begin{abstract}
The era of globalization has made various kinds of changes. This change has an impact on higher economic competitiveness. One of the impacts of this is the creation of the MEA which is an attempt by countries in Asia to face global competition. This study uses an explanatory method which aims to explain the causal relationship and test the hypothesis (hypothesis testing study). The secondary data studied are panel data between 17 countries, namely ASEAN countries, several South Asian countries and several East Asian countries in the period 2007, 2010, 2012, 2014, 2016, 2018. Based on the results of the study, there is a partial significant effect on performance logistics, exchange rate and net export to global competitiveness in accordance with trade competitiveness diagnostics theory. Increasing international trade activities along with improved logistics performance, exchange rates, interest rates and net export is a key strategy to develop economic competitiveness in the global market.
\end{abstract}

Keywords: Globalization; MEA; Competition

\section{Introduction}

The era of globalization has made various kinds of changes. This change has an impact on higher economic competitiveness. Indonesia and other countries in the region are required to further improve their economic competitiveness against global competition. Indonesia, which is located between the continents of Asia and the continent of Australia and between the Atlantic Ocean and the Indian Ocean, requires adequate logistics infrastructure, a reliable logistics system, and professional logistics sector human resources to support its competitiveness in the global market in order to realize the expected economic progress. as well as other ASEAN countries and South Asian and East Asian countries.

ASEAN member countries implemented the MEA on December 31, 2015, but the leaders of ASEAN countries had prepared its implementation when the ASEAN Framework Agreement on Economic Cooperation was signed in 1992 (Coordinating Ministry, 2015). The 
implementation is carried out in stages through the Regional Trade Agreement (RTA) in the form of the ASEAN Free Trade Agreement (ARFT), the MEA which has 4 (four) pillars which aims to form a single market in the ASEAN region that is competitive by integrating the production base, by creating equitable economic development. and production networks can be connected between countries. Not only liberalization is a commitment in the AEC, but also economic reform, facilities and regulatory alignment. The implementation of the MEA through various provisions such as the elimination of tariffs, simplification and alignment of capital market policies, investment facilities and trading facilities as well as facilities for skilled labor have essentially been achieved for these various activities.

An important step for the MEA is to integrate the economies of ASEAN countries. The implementation of the MEA for Indonesia is a way to benefit from economic globalization. Wide market opportunities with the implementation of regional economic integration with the implementation of the MEA can increase investment through trade competition between ASEAN countries. Thus, a country's trade balance can be in a surplus or a deficit. The role of the Central Bank in stabilizing the macroeconomy is particularly relevant in controlling interest rates and exchange rates. The main factors influencing the current deficit in the fourth quarter of 2011 are domestic factors and external factors. The performance of the processing industry is strongly influenced by commodity prices because the basis is natural resources (SDA). The fall in commodity prices will result in a decline in the country's exports.

Compared to the 1980s, the share of Indonesia's industrial sector has decreased, as well as economic growth which has also experienced a decline. The dominance of industry that has a domestic orientation has resulted in weak investment policies and a lack of connection in the global market. This is also influenced because the domestic industry is an industry that has a fairly high import content. Indonesia's economic potential basically exceeds its current performance. To develop the economy, Indonesia can take advantage of the rise of Asia. Indonesia's potential in terms of demography, geographic location and natural resources is a separate incentive. Similarly, other ASEAN countries, several countries in South Asia and East Asia with their respective economic conditions have improved their economic performance through various macroeconomic policies, especially in terms of monetary and fiscal policies, including increasing competitiveness.

In optimizing each country's economic potential, economic transformation needs to be carried out, especially through strengthening logistics performance as a support for industrial connectivity in international markets that can increase competitiveness. The center of economic change is industry which is the driving force of growth and the absorption of a large number of workers so that it can push it to become a more developed country.

Bank Indonesia and other researchers have conducted studies on the MEA. In the analysis of the impact of various liberalizations; Agung, et al. (2011) concluded that weak economic competitiveness caused Indonesia to be the aggrieved party to the AEC. In the study of Ridhwan, et al. (2015), stated that the benefits of the MEA are not the same between members. Indonesia's growth is still lower than other ASEAN countries. The Boston Consulting Group (BCG) survey in 2014 also showed that MEA is a threat to companies, while other countries such as companies in Malaysia and Singapore see AEC as an opportunity. The AT\&K report in 2013, as a representation of global business players, states that companies affected by the MEA are companies that only focus on local or domestic markets. This causes Indonesian companies to have low competitiveness.

In the perspective of trade competitiveness diagnostics, one way to determine international trade activities is economic competitiveness in the global market. Countries that have high competitiveness in the export market generally have a superior domestic market because the 
export market has high competition. Trade and productivity have a reciprocal relationship. Productive companies will transform into exporters and with the increase in the export market, these companies will become more productive. Reis and Farole (2012) mention that internal factors are the main obstacles such as financing, customs, logistics and lack of competition. In the midst of low industrial connectivity to international markets, improving national logistics performance can be seen as a key strategy to increase global competitiveness and sustainable economic growth.

As a measure of global competitiveness from the World Economic Forum, the GCI measures and ranks a country's global competitiveness based on the twelve (12) pillars that determine economic competitiveness that can enable the national economy to grow sustainably and create prosperity. These twelve pillars measure the national economic and business environment of a country, both quantitatively from various national and international organizations and qualitatively based on a survey of executive opinion of companies that do business in the country (forum's executive opinion survey). The 12 pillars are: 1) Institutions; 2) Infrastructure; 3) Macroeconomic stability; 4) Health and primary education; 5) Higher education and training; 6) Goods market efficiency; 7) Labor market efficiency; 8) Financial market sophistication; 9) Technological readiness; 10) Market size; 11) Business sophistication; and 12) Innovation.

Indonesia's improvement in global competitiveness after the implementation of the MEA in 2018 was obtained from the improved performance of macroeconomic stability and market size which exceeded the performance before the implementation of the MEA in 2014. Performance of institutions, infrastructure, higher education and training, labor market efficiency, financial market sophistication, technological readiness, and business sophistication fell in 2016, but rose in 2018 with a higher performance than before the implementation of the MEA. While the performance of health and primary education and goods market efficiency decreased in 2016, although it increased in 2018, it has not been able to exceed its performance before the implementation of the MEA. As for performance of innovation, although it increased in 2016, it fell in 2018.

Based on the background review, the central theme of this research is: "Logistics performance, Exchange Rate, Interest Rate and Net Export influence on Global Competitiveness and its implications for Growth Economy (Case Study of ASEAN Countries, several South Asian Countries and several East Asian Countries)". Through this research, it is hoped that strategies for achieving sustainable economic growth can be developed through increasing global competitiveness based on strengthening logistics performance, exchange rates, interest rates and net export as supporting industrial and trade connectivity in international markets.

\section{Literature Review}

\subsection{Logistics Performance}

The main activities in historical logistics performance and physical distribution consist of transportation and storage. Transport and storage activities are 2 different activities. According to Swastha, transportation is the process of bringing goods from one place to another by using roads that use channels between institutions and consumers [1]. Meanwhile, storage is the process of maintaining as long as the goods are still needed. The management of the flow of goods can be carried out by logistics management starting from taking goods from suppliers 
and sending them to their storage and distribution areas. Services and information about products are provided in logistics management. Strategically that logistics is a process of managing the flow of protection of a number of raw materials, inventories in process, and inventories of finished goods from the point of origin to the point of consumption (Daniel, 2001:31).

Distribution channels to consumers are carried out through a logistics process. The economic sector is influenced by the logistics system, especially cargo transportation, which generally has a very long distance from one place to another. Usability, time and place constitute logistics operations and are important aspects of corporate and government operations. The emphasis on logistics management is how to manage goods starting from planning, determining needs, procurement, storage, distribution, maintenance, and elimination of goods to achieve the goals that have been set. Chopra (2007) defines supply chain management as a holistic and strategic approach in terms of demand, operations, purchasing, and logistics process management.

Logistics management is a responsibility to create and manage systems to cope with the flow of raw materials and finished goods [1]. According to Bowesox (2002:13), logistics management is unique because it is one of the oldest but also youngest corporate activities. Logistics activities (location, facilities, transportation, inventory, communication, and management \& storage) have been carried out by people since the beginning of commercial specialization. Logistics is an integral part of channel activities. The general task of logistics management is to strike a balance between costs and income to achieve a certain profit [1].

In the logistics process, functions are implemented or performed simultaneously by channel members. The movement of goods in one direction to the customer's final location is the most economical physical movement. According to Simamora (2000:731), customer service is a channel system that has the ability to provide satisfaction for the needs of customers, industrial users, or channel intermediaries.

Time of order cycle is the time required by the company to receive, process, and deliver an order. Reliability is related to the reliability of delivery which is an element of service for companies in distributing goods on time. Communication between buyers and sellers early on both parties can find solutions to problems faced as soon as possible. Ease of a flexible system so that it can accommodate needs for various customers. According to Irawan, the choice of logistics managers to carry out a combination of transportation and storage in the marketing channel [2]. Logistics channel is a combination of own logistics and general logistics which can be categorized as moving goods in 3 kinds of options, namely: fully using own tools; using agents; using a combination of general logistics and own logistics.

\subsection{Global Competitiveness}

According to Porter (1990) in the PPSK-BI book (2008) states that "productivity" at the national level is a concept of competitiveness that can be applied at the national level. Productivity is the output value obtained from a series of processes with a number of inputs. The World Bank states that "the magnitude and rate of change in value added per unit of input is a measure of competitiveness". The concept of national competitiveness views competitiveness broadly and does not only speak at the micro level of the company, but also at the level outside the company. These aspects can be firm-specific, region-specific, and country-specific.

The World Economic Forum (WEF), the publisher of the Global Competitiveness Report, defines global competitiveness as "the ability of the national economy to achieve high and 
sustainable economic growth". Appropriate policies and appropriate institutions as well as other economic characteristics that support the realization of high and sustainable economic growth are the focus of economic growth. The Institute of Management Development (IMD), the publisher of the World Competitiveness Yearbook, defines global competitiveness as "the ability of a country to create added value in order to increase national wealth by managing and processing, attractiveness and aggressiveness, globality and proximity, as well as integrating relationships. these relationships into economic and social models". Global competitiveness has a non-uniform definition, although there is a common opinion about what should be done to increase global competitiveness [3].

In the Global Competitiveness Report, the World Economic Forum measures and ranks a country's global competitiveness through the Global Competitiveness Index (GCI) based on twelve (12) pillars that determine economic competitiveness that enable the national economy to achieve sustainable economic growth and long-term prosperity. These twelve pillars measure the national economic and business environment of a country, both quantitatively from various national and international organizations and qualitatively based on a survey of executive opinion of companies that do business in the country (forum's executive opinion survey). The determinants of competitiveness can be grouped into the first group of basic requirements pillars, namely the key to a factor-driven economy (an economy driven by basic factors) as the first stage of development and country competitiveness, the second group of efficiency enhancing pillars (efficiency enhancers), which are the key to an efficiency-driven economy as the second stage of development and country competitiveness and the third group of pillars of innovation and sophistication factors, which is the key to an innovation-driven economy (innovation-driven economy) as the third stage of development and country competitiveness.

Starting in 2018, the World Economic Forum has adjusted its GCI measurement methodology to the concept of the Industrial Revolution 4.0 which emphasizes the importance of human capital, agility (the ability to operate quickly and easily), resilience (the ability to recover quickly from various difficulties), and innovation to achieve economic success. Within the framework of GCI 4.0, a country's global competitiveness is organized into 12 pillars of productivity main drivers in four (4) categories, namely: enabling environment, human capital, markets, and innovation ecosystem. The Enabling Environment category consists of the following pillars: 1) Institutions; 2) Infrastructure; 3) ICT (Information and Communication Technologies) adoption; 4) Macroeconomic stability. The Human Capital category consists of pillars: 5) Health and 6) Skills. The Markets category consists of the following pillars: 7) Product market; 8) Labor market; 9) Financial systems; and 10) Market size. The Innovation Ecosystem category consists of the following pillars: 11) Business dynamism and 12) Innovation capability. Although in a different category, where the indicators have also been modified - some are maintained and some are updated, broadly speaking, the pillars in GCI 4.0 are relatively the same as the previous ones. GCI 4.0 is no longer aggregated based on the weighting of pillar groups/categories according to the stages of development (factor-driven economic, efficiency-driven economic, innovation-driven economic) of each country. In GCI 4.0, each productivity pillar is given equal weight.

\subsection{Economic Growth}

According to Rostow [4], economic growth can be defined as a process that causes changes in people's lives, namely changes in politics, social structure, social values, and the structure of economic activity. According to Meltzer and Scott (2015), economic growth is 
related to various economic indicators, including the imposition of taxes, labor productivity and the development of know-how.

According to Smith [4], economic development can be influenced by population development, when the number increases, the market share also expands and specialization of the economy also increases, which causes economic activity to increase even higher. Economic development is an activity that can accelerate the increase in per capita income [4]. Development in the long term will also increase the real income of the population per capita along with the improvement of the institutional system [5]. Meanwhile, development aims to improve the lives of the community and its citizens. Economic development is related to per capita income and national income. The increase in national income and per capita income from time to time can be used as a basis for calculating economic growth and the development of the level of welfare of the people of a country. Economic development is a process to increase the income per capita of the population in the long term, where economic development is closely related to economic growth. Development is categorized as successful if there is an increase in the community's economy.

According to Hanafiah (1987), currently development must be viewed comprehensively or with many dimensions, because Gross Domestic Product (GDP) is not the main goal and measure of development success. Development planning must be oriented to the regional aspect, where the function and role of each region is also seen as its role and function in national economic development. Regional planning activities should include 3 related activities, namely: 1) inter-regional planning; 2) planning between locations of an area; and 3) location planning for each sector.

Regional development planning begins with determining the role of the development sector in achieving growth targets, which is then followed by investment activities, both government and private investment. Limited resources and funding require the sensitivity of the government to choose the scale of development priorities. It is impossible for a region to fund all development sectors at the same time due to limited sources of funds, so it is necessary to determine the leading sector to be the driving force for other sectors.

A sector can be designated as a priority sector if the sector has a dominant role, to achieve economic development goals and has great linkages with other sectors, forward or backward. In determining development priorities for leading sectors, it is necessary to know the impact between sectors in the economy, namely the impact of inter-sectoral linkages that provide an overview of sectors that have a dominant contribution, either for the sector itself or for other sectors. Thus, policies related to regional economic planning will be prioritized in this sector.

\section{Methodology}

Research variables consist of independent variables, intermediate variables, and dependent variables. The independent variable is Logistics Performance which consists of: Customs, International Shipments, Logistics Services Quality, Tracking and Tracing, Timeliness (X1), Infrastructure (X2), Exchange Rate (X3), Interest Rate (X4) and Net Export (X5) and the intermediate variable is Global Competitiveness (Y) and the dependent variable is Economic Growth (Z). The data collection technique used in this research is a documentation study. Documentation studies were carried out at the World Bank in the Logistics Performance Report and Economic Growth Report as well as the World Economic Forum (WEF) in The Global Competitiveness Report as well as the Central Statistics Agency (BPS) and Bank Indonesia (BI) directly or through the websites of each institution. The data collected are 
logistics performance index data, exchange rate data, interest rate data, net export, global competitiveness index, and Gross Domestic Product (GDP) between ASEAN countries, several South Asian countries and several East Asian countries for 6 years, namely 2007, $2010,2012,2014,2016$, and 2018. The number of observations collected is 17 countries x 6 years $=102$ observations. While the execution uses the EVIEWS econometric program.

The research design uses an explanatory study or hypothesis testing study with a quantitative approach with the aim of explaining the results of hypothesis testing about the relationship between variables, which explains the causal relationship (cause and effect) or the influence between variables as has been modeled in the research paradigm, namely the influence between performance dimensions. Logistics, exchange rates, interest rates and net exports on global competitiveness and their impact on economic growth. The quantitative approach is in line with the use of quantitative data in the measurement of variables and quantitative/statistical methods in the analysis of the influence between variables (Cresweel, 2010: 24). The statistical method used in the study or linear regression analysis was the Ordinary Least Square (OLS) method to determine the effect between variables with the recursive model. Regression analysis is used to examine the pattern of the relationship between one or more causal variables (exogenous) to one effect variable (endogenous). The entire data processing and analysis process in this study was carried out with the help of the EViews 10 for Windows computer program.

\section{Results and Discussion}

The results of the analysis of the model of the effect of logistics performance, infrastructure, exchange rates, interest rates and net exports on global competitiveness and their implications for economic growth show the same results. Logistics performance (customs, international shipments, logistics services quality, tracking and tracing, timeliness), infrastructure, exchange rates, interest rates and net export together or simultaneously affect global competitiveness and have implications for economic growth. If compared, the influence model with the highest level of conformity is the model of the effect of logistics performance, exchange rate, interest rate and net export on global competitiveness with an adjusted coefficient of determination (Adjusted $\mathrm{R}^{2}$ ) of $95.60 \%$. Furthermore, the model of the influence of global competitiveness on economic growth with Adjusted $\mathrm{R}^{2}$ of $67.020 \%$. It appears that the model of the effect of logistics performance, exchange rate, interest rate and net export on global competitiveness and its implications for economic growth has met the level of model suitability or adequate predictive ability, which is above $50 \%$ (Baye's measure).

The results of the study which show that there is a partially significant effect of logistics performance, exchange rate and net export on global competitiveness are in accordance with trade competitiveness diagnostics theory. Increasing international trade activities along with improved logistics performance, exchange rates, interest rates and net export is a key strategy to develop economic competitiveness in the global market. As referred to by Reis and Farole (2012), the low performance of logistics, the exchange rate and the value of net exports is one of the main obstacles for developing countries, which are behind the border, to compete in international trade. Through logistics performance, high exchange rates and net export, the process of delivering the right amount of finished goods/materials to the right place at the right time and with the lowest total cost can be carried out effectively [6]. Increased connectivity of production sectors on international markets due to improved logistics performance, exchange rates, interest rates and net exports will boost global competitiveness. The results of this study 
support the results of Anatan's research (2010) which shows that logistics performance, exchange rate and net exports are determinants in achieving competitive advantage of an entity. Meanwhile, the partial insignificant effect of interest rates indicates the ineffective role of the interest rate performance aspect in achieving global competitiveness.

The simultaneous influence of logistics performance, exchange rate, interest rate and net export on global competitiveness shows that the integration of logistics performance improvement in all aspects; both customs, infrastructure, international shipments, logistics services quality, tracking, tracing, timeliness as well as the performance of exchange rates, interest rates and net export synergistically have the ability to increase global competitiveness. Similarly, the research findings on the positive effects partially or simultaneously from customs, infrastructure, international shipments, logistics services quality, tracking, tracing, timeliness and exchange rates, interest rates and net export show that the aspects of logistics performance, exchange rates and interest rates increase. and this net export is effectively able to encourage higher global competitiveness. The logistics performance is a key strategy for achieving global competitive advantage and has a more dominant influence. Logistics performance serves as a primary factor. Meanwhile, the exchange rate, interest rate and net export are secondary factors. In improving economic connectivity, both are also the base factors that determine the overall supply-chain performance. Increasing the performance of logistics infrastructure and the quality of logistics services will increase global competitiveness and at the same time encourage the effectiveness of overall logistics performance, including aspects of customs, logistics services quality, international shipments, tracking and tracing, timeliness and exchange rates, interest rates, net export in achieving global competitive advantage. Improved infrastructure performance is indicated by the increasing quality of trade and transportation infrastructure, both ports, airports, rail networks, road networks, and information technology.

The results of the study which show that there is a positive influence of global competitiveness on economic growth are in accordance with the diagnostic theory of trade competitiveness and the theory of economic growth. As Kuznets refers to [4], increasing a country's global competitiveness will increase economic growth or the growth of a country's ability to provide various types of economic goods to its population. This capability grows in line with technological advances as well as the institutional and ideological adjustments it requires as a reflection of increasing global competitiveness. High global competitiveness, namely high productivity, will enable the national economy to achieve sustainable economic growth and long-term prosperity (Porter, 1990; World Bank). Increased competitiveness is marked by increased productivity of basic requirements (institutions, entire infrastructure, macroeconomic stability, health and primary education) as a factor-driven economy; efficiency enhancers (higher education and training, goods market efficiency, labor market efficiency, financial market sophistication, technological readiness, market size) as an efficiency-driven economy; and innovation and sophistication factors (business sophistication, innovation) as drivers of the innovation-driven economy (World Economic Forum, 2018).

All the results of this study develop the results of research by Bizoi and Sipos (2014) and show that global competitiveness is an intervening variable that mediates the effect of logistics performance on economic growth. In their comparative study, Bizoi and Sipos (2014) show that European Union countries with better logistics performance are able to produce higher Gross Domestic Product. 


\section{Conclusions and Suggestions}

\subsection{Conclusion}

Based on the formulation of the problem and research objectives, this study produces the following conclusions:

a. The regression results of the 3 models, namely the Common Effect Model (CEM), Fixed Effect Model (FEM) and Random Effect Model (FEM), after the Chow Test (Chow Test) obtained the result that the best or the right model for estimating panel data was FEM. and then carried out the Hausmann Test (Hausmann Test) and also get the results that the best or the right model for estimating panel data is FEM. Thus, FEM is the model chosen to estimate panel data;

b. Based on the best and most appropriate model for estimating panel data, the Fixed Effect Model (FEM) has been selected, concluded as follows:

1. Logistics performance consisting of customs, international shipments, logistics services quality, tracking and tracing, timeliness $\left(\mathrm{X}_{1}\right)$, partially positive and significant effect on competitiveness. From the results of this modeling, it shows that the better the quality of Logistics Performance, the better the Global Competitiveness of a country;

2. Infrastructure reliability $\left(X_{2}\right)$, partially positive and significant effect on competitiveness. From the results of this model, it shows that the better the quality of the infrastructure, the better the Global Competitiveness of a country, this finding is in line with the Null-Hypothesis;

3. Exchange Rate $\left(X_{3}\right)$, partially has a negative effect or is in the opposite direction to competitiveness (negative relationship). However, the results of the execution of this model show that the effect of the exchange rate on competitiveness is significant. From the results of this model, it shows that the better or stronger the performance of the exchange rate will increase the Global Competitiveness of a country, this finding is in line with the Null-Hypothesis;

4. Interest rate $\left(\mathrm{X}_{4}\right)$, partially also has a negative affect or opposite direction to the competitiveness of the (negative relationship) means that the lower the interest rate will increase competitiveness. However, the results of this model show that the effect of interest rates on competitiveness is not significant. This insignificance is thought to be due to the limited number of observations or tabulation errors that occur in the data sources referred to by the researcher. Alternatively, these variables were excluded from modeling, but the researchers did not choose this alternative to the consideration of economic theory and emphirical variable interest rate $\left(\mathrm{X}_{3}\right)$ has an important role in a variety of macroeconomic and monetary modeling, so the $\mathrm{X}^{4}$ maintained. Another consideration is the feasibility of the model as reflected in the F test which shows that $\mathrm{F}$ count $>$ F table $(105.6809>2.3000)$

5. Net Export $\left(X_{5}\right)$, partially has a positive and significant effect and is in line with competitiveness (positive relationship). From the results of this model, it shows that the increasing export and import activities of a country with a positive net export will increase the global competitiveness of a country.

6. Logistics performance consisting of customs, international shipments, logistics services quality, tracking and tracing, timeliness $\left(\mathrm{X}_{1}\right)$, Infrastructure $\left(\mathrm{X}_{2}\right)$, Foreign Exchange Value $\left(\mathrm{X}_{3}\right)$, Interest Rate $\left(\mathrm{X}_{4}\right)$ and Value Net Exports $\left(\mathrm{X}_{5}\right)$ have a simultaneous effect on global competitiveness, this is evidenced by the F-Calculated Value $>$ F-Table which is $105.6809>2.300$; 
c. Global competitiveness has a positive effect on economic growth. This finding shows that increasing global competitiveness has the ability to increase economic growth. Increasing global competitiveness is indicated by increasing productivity of basic requirements (institutions, entire infrastructure, macroeconomic stability, health and primary education) as a factor-driven economy; efficiency enhancers (higher education and training, goods market efficiency, labor market efficiency, financial market sophistication, technological readiness, market size) as an efficiency-driven economy; and innovation and sophistication factors (business sophistication, innovation) as the driving force of the innovation-driven economy. The forecasting ability of the economic growth model, which is relatively lower than the global competitiveness model, has theoretical implications that there are other factors other than global competitiveness that also affect economic growth;

d. Indonesia's position in global competition in 2018 as shown in this model is still ranked 45th in the world. Indonesia's global competitiveness among ASEAN countries is below Singapore (6.01 - ranked 2), Malaysia (5.46 - ranked 25th), and Thailand (5.05 - ranked 38th), but is still superior to Vietnam (4.49 - rank 77). Meanwhile, Hong Kong (5.53 ranked 6), Japan (5.49 - ranked 9) and South Korea (5.07 - ranked 26). The highest ranking was achieved by the United States, which was ranked 1st in the world.

\subsection{Suggestions}

Based on the research results and interpretations and conclusions, the relevant suggestions in this study are as follows:

a. Indonesia must conduct aggressive international trade by conducting continuous research related to strengthening logistics performance and competitive advantage of Indonesian export commodities that have high competitiveness, both processed industry, mining products, processed forest and plantation products, as well as people's industrial products.

b. Multilateral and bilateral cooperation should be encouraged by utilizing embassies and exchange of ideas and information through the OECD, ASEAN, G7, G20, World Bank, IMF, and other multilateral institutions including mutually beneficial bilateral cooperation.

c. As a practical suggestion, to increase global competitiveness which can have implications for economic growth; it is suggested to the government to evaluate the national logistics performance development policy; especially the carrying capacity of customs, logistics services quality, international shipments, tracking and tracing, timeliness and its integration with other aspects of logistics performance. Infrastructure is the basic determinant of supply chain performance as a whole in increasing national (intra-regional and inter-regional) and international economic connectivity. The government is also advised to encourage sustainable global competitiveness based on policies to improve logistics performance in a sustainable manner.

d. The government continuously encourages the participation of large businesses and UMKM to take advantage of the built-in connectivity in developing investment and increasing productivity.

e. Encouraging sustainable economic growth through policies to increase global competitiveness on the twelve pillars of economic productivity gradually from basic requirements (economy factor-driven); efficiency enhancers (economy efficiency-driven), to innovation and suffocation factors (economy innovation-driven).

f. As an academic suggestion, it is recommended for other researchers to expand the scope of research by involving external factors other than logistics performance, exchange rates, interest rates, net export and global competitiveness which theoretically also affect global 
competitiveness and economic growth. To improve the forecasting ability of the economic growth model which is relatively lower than the global competitiveness model, other factors that are recommended to be investigated are aggregate expenditure, such as: public consumption, government spending, investment, and export-import; as well as the contribution of economic sectors, both the primary (agricultural), secondary (industrial) and tertiary (services) sectors.

\section{References}

[1] Swastha, B. Manajemen Pemasaran Modern. Yogyakarta: Liberty. (1990).

[2] Basu Swastha, DH dan Irawan. Modern Marketing Management. (1990).

[3] Sachs, Torsten; Wille, Christian; Boike, Julia; Kutzbach, Lars: Eddy. Ecovariance Raw Data From Samoylov Station, Lena River Delta, Siberia In 2006. GeoForschungsZentrum Potsdam, PANGAEA, https://doi.org/10.1594/PANGAEA.745602. (2008).

[4] Jhingan, ML. Development Economy and Planning. Translated by Guritno, D. Edisi ke-1. Cetakan ke-10. Jakarta. PT. King Grafindo Persada. (2004).

[5] Arsyad L. Development Economy, Edisi kelima. Yogyakarta: UPP. (2010).

[6] Bowersox, DJ. Supply Chain Logistics Management. New York. The. McGraw-Hill Companies, Inc. (2002). 